\title{
İnfodemik Dünya: Sağlık Habercilerinin Pandemi Sürecinde İnfodemiye İlişkin Tespit ve Önerileri
}

\author{
Infodemic World: Detections and Suggestions of Health Journalists Regarding Infodemic During \\ the Pandemic Process
}

Şükran Pakkan Tosun, Dr. Öğr. Üyesi, İstinye Üniversitesi İletişim Fakültesi, E-posta: sukranpakkan@gmail.com

https://doi.org/10.47998/ikad.975745

Covid-19, Salgın, İnfodemi Medya, Sağlık Gazeteciliği.
Anahtar Kelimeler:

Öz

Covid-19 salgını; geleneksel medya araçları ve sosyal medya platformlarında yanlış ve yanıltıcı bilgi firtınası yaratmakla kalmamış, kitle iletişim araçları aracilığıyla doğru bilgiye ulaşmak için güvenilir sistemlere ihtiyaç duyulduğunu bir kez daha belirgin olarak ortaya çıkarmıştır. Dünya Sağlık Örgütü'ne göre, kontrolsüz, eksik ve yanlış bilgilerin Covid-19 virüsünden daha hızlı yayılmasına neden olan infodemik ortam, psikolojik paniğe, yanıltıcı tıbbi tavsiyelere ve sosyal medyada dramatik bir yapısal bozulmaya neden olmuştur. Pandemi süreci, gerçekle ilgisi olmayan söylentilerin ve yanlış bilgilerin virüsle yarıșırcasına hızla ilerlemesi nedeniyle, gazetecilikte sağlık gibi önemli alanlarda uzmanlaşmanın ve kriz yönetiminin önemini bir kez daha ortaya koymaktadır. Bu bağlamda, bu makale infodeminin salgın sürecine etkisine odaklanarak uzman sağlık gazetecileri perspektifinden bir değerlendirme sunmaktadır. Medyanın pandemi haberciliğine nasıl yaklaştığını belirleme noktasında bu çalışmayı gerekli kılan sorun, Covid-19'un ortaya çıkışı ile, bütün dünyayı etkisi altına alan krizin medyadaki çerçevesinin sorunu hafifletmeye (ya da tırmandırmaya) nasıl etkili olduğu ve sağlık gazeteciği etik kriterlerinin ele alınıp alınmadığı sorularında gizlidir. Bilgi tüketim alışkanlıkları ve medyanın haber üretim süreçlerinin analiz edilmesi amacıyla yürütülen çalışma kapsamında, ulusal medyada görev yapan kıdemli sağlık gazetecileri ile görüşülmüştür. Gazetecilere göre, yanlış bilgilerin yayılmasında en fazla "konunun uzmanı olmayan hekimlerin yaptıkları paylaşımlar" ile "bu hekimlerin verdiği yanıltıcı içerikleri sosyal medya hesaplarında paylaşan gazeteci, siyasetçi ve fenomenler" etkili olmaktadır. İçerikleri sorumsuzca paylaşan diğer sosyal medya kullanıcıları da yanlış bilginin yayılmasına etki etmektedir. Çalışma ile bilime dayalı ve objektif haberciliğin posttruth hakikat çağında her zamankinden çok daha önemli olduğu gerçeğini kanıtlamakta, yanlıș bilgi ve komplo teorilerinin medya aracılı̆̆ıla toplumun geniş kesimlerine erişmesinin önüne geçilmesi amacıyla öneriler ortaya koymaktadır.

\section{Keywords:}

Covid-19, Epidemic, Infodemic, Media,

Health Journalism.

\section{Abstract}

The Covid-19 pandemic has created false and misleading information in the media and media platforms, and has once again clearly revealed the need for reliable systems to reach accurate information through social media and mass media. According to the World Health Organization, during Covid-19 uncontrolled, incomplete and incorrect information spread faster than the virus and also has caused psychological panic, misleading medical advice, and a dramatic structural breakdown in social media. Due to the rapid progress of rumors and false information that have nothing to do with reality in the pandemic process, once again revealed the importance of specializing in important fields such as health in journalism and crisis management. In this context, this article offers an evaluation from the perspective of expert health journalists, focusing on the impact of the infodemic on the epidemic process. The problem that makes this study necessary to determine how the media approaches pandemic reporting is how the crisis affecting the whole world has been effective in easing or escalating the problem through the media and how the ethical criteria of health journalism are handled. Within the scope of this study, which was carried out to analyze the information consumption habits and news production processes of the media, senior health journalists working in the national media were interviewed. According to the journalists, "the posts written by physicians who are non-experts on the topic" and "journalists, politicians and phenomena who share the misleading content given by these physicians on their social media accounts" are most effective in the spread of misinformation. Other social media users who share content irresponsibly are also effective in spreading misinformation. The study highlights that science-based and objective journalism is more important than ever in the era of post-truth, and that misinformation and conspiracy theories should be prevented from reaching large segments of society through the media. 


\section{Kavramsal Çerçeve}

\section{Kriz Dönemlerinde Haber ve Bilginin Yayılımı}

Kriz, eski Yunancada "karar vermek, ayırmak, seçmek” anlamına gelen 'krinein' sözcügünden türetilmiştir ve genelde tıp alanında hastalıkların seyrini tarif etmek ile ilgili durumlarda kullanılır. Zor ve sıkıntılı zamanları tanımlamak için kullanılan "kriz dönemi" kavramı ise genellikle toplumun büyük kesimi etkileyen olağanüstü halleri anlatmak için tercih edilir. Kriz dönemleri, toplumun bilgi edinme ihtiyacının artmasından dolayı, krizden etkilenenlerin ruh durumlarını, tepki ve duygularını yönetebilme gücüne sahiptir.

İnsanları bilinmeyenden daha çok korkutan hiçbir şey yoktur. Bu nedenle insanı kriz dönemlerinde içine düştüğü korku ve endişeden kurtaracak olan; yakın ve uzak çevresinde yaşananlardan haber alma ihtiyacının karşılanmasıdır. Toplumsal yaşamdaki belirsizliğin yarattığı bu korku atmosferini "risk" kavramıyla açıklayan Furedi, bu noktada medyanın risklerin algılanış şeklinde önemli bir rol oynadığını vurgulamaktadır. Kriz dönemlerinde halkın doğru bilgilendirilmesi, temel bilimsel verilere ulaşması, kaygı ve endişelerin tartışıldı ğı bir ortam yaratılması için otorite ile halk arasında açılan pencere görevini medya görür. Medya, halkın görünmeyen gözü, kulağı ve sesidir (Pakkan ve İldaş, 2020: 232).

Son yüzyılda risk ve toplum çalışmalarından elde edilen geri bildirimler incelendiğinde salgın hastalıkların öne çıktığı görülmektedir. Salgınlar sırasındaki yanlış bilgilendirmenin etkileri Orta Çağdan bu yana süregelir. İnsanlık tarihi boyunca kitlesel ölümlerin en önemli nedeni de salgın hastalıklar olmuştur. Veba nedeniyle yayılan üç büyük salgında dünya çapında 60 milyonun üzerinde ölüm gerçekleşmiş, sadece 1928 yılında İspanya'da H1N1 grip salgını yüzünden 50 milyondan fazla kişi hayatını kaybetmiştir (Uçar, 2019). Ancak etkileri günümüzde yaşanan Covid-19 salgınıyla kıyaslanmayacak derece azdır. İspanyol gribi salgını sırasında insanlar, haberleri ve bilgileri hızlı bir şekilde paylaşmak için 21. yüzyılda sahip olunan iletişim kaynaklarına da sahip değillerdi. Sosyal tarihçiler, bu salgınının halkın hafızasında bu denli az iz bırakmasının sebebini, "Salgının Birinci Dünya Savaşı'nın gölgesinde kalması" olarak gösterseler de tarihe "unutulmuş pandemi" olarak geçmiştir (Honigsbaum, 2013). Khoros tarafından 2020 yılında yayımlanan İspanyol salgınına ilişkin Minneapolis ile ilgili halk sağlı̆gı raporu, "virüsle ilgili kritik bilgilerin posta çalışanları, izciler ve öğretmenler aracılığıyla yayıldığını" göstermektedir. (Kushner, 2020).

Daha sonraki dönemlerde ortaya atılan "asılsız sağlık haberi (fake health news)" kavramı da "gelişen medyanın yan etkisi" olarak tanımlanmakta ve komplo teorileri, şahsi fikirler ve dedikoduların dayanak olduğu yanıltıcı haberleri tanımlamaktadır. "Aşıların otizme sebep olduğu”, "aşıların kısırlık yaptığı, "şehir sularının klorlanmasının sağlığımıza zarar verdiği”," "tek bir hap içerek zayıflanabileceği”", "bol bol tereyağı yemenin faydalı olduğu", "kudret narı ve tuz yemenin Ebola virüsünü engellediği”, "Meryem ana otunun doğuma yardımcı olduğu" gibi birçok bilgi asılsız sağlık haberlerine örnektir (Uçar, 2019). 
Doğal afet, savaş, çatışma, terör gibi kriz durumları, asılsız bilgilerin önüne geçmek için habercilikte kriz yönetimini şart kılar. Geleneksel medya bu kriz dönemlerinde uzman meslek sahipleri tarafından etik koşullar ve sınırlar içerisinde icra edilen bir ortamı yaratabilirken, sosyal medya ise isteyen herkesin, elindeki her bilgiyi yayabileceği, bireysel kullanıma açık bir platform haline gelebilir. 2000'li yıllarda sosyal medyanın, geleneksel medya gibi, genel kitleye erişim sağlayan, kolay ulaşılabilir, yeni ve kullanışlı bir araç olarak insan hayatının merkezi haline gelmesi denetim ortamının kısıtlanmasına da neden olmuştur. Yapılan çalışmalar "İnsanların sadece güncel haberlere anında erişimi sağlamakla kalmadığını, aynı zamanda kişisel ve ticari bilgi akışını sağlamak için Facebook ve Twitter gibi platformları da iletişimlerinin ana unsuru haline getirdiğini” göstermektedir. $\mathrm{Bu}$ çalışmalarda hükümetlerin, siyasi otoriteler ve ticari kuruluşlar tarafından kitlelere erişmek amacıyla devrimsel bir fırsat olarak ele alınan sosyal medyayı, büyük bir bilgi savaşı ve kirliliğine de sürüklediği görülmüştür (Gough, vd., 2017).

Oysa, bilgiyi yayma sorumluluğuna sahip geleneksel kitle iletişim araçları gibi sosyal medya da kamuoyunu şekillendirme ve karar vermede güçlü bir etkiye sahiptir. Schram "Haberin, insanların zihninde var olduğunu" savunurken, "Haber, bir olay değil; olaydan sonra algilanan bir durumdur" demektedir (Schram, 1993). Luhmann ise teknolojik imkanlardaki büyük artışın insanın risklere dikkat etmesine daha çok sebep olduğunu vurgular (Furedi, 2001). McLuhan ve Powers (2001: 15-20), "21. yüzy1lda dünyanın her yerinden veri alabilen insanların süratle kendi kendinin sonunu getireceğini” söylemiştir. Anthony Giddens (2001) da "imal edilmiş riskin bilimsel ve teknolojik gelişmelerin her yere üşüşmesiyle üretildiğini belirtmekte ve küresel düzenin belirleyicisinin risk olduğuna" dikkat çekmektedir.

Özellikle savaş, terör, saldırı, salgınlar, ekonomik bunalım, beklenmedik siyasi durumlar, doğal afet ve kaza gibi olağanüstü olaylarlailgili "kriz yayıncılığı" dönemlerinde, izleyicinin merakını artırmak, bir öykü yaratmak, çeşitli dramlar ile kamuoyuna bir duyguyu ajite etmek uğuruna üretilen "yapay/abartı" içerikler, günümüzde neredeyse "doğal/sıradan" karşılanmaktadır (Pakkan, 2020). Bu nedenlerle kriz haberciliği "olağandışı" bir habercilik profesyonelliğini zorunlu kılmaktadır. Bu nedenle "pandemi gibi sağlık krizleri sürecinde, hızlı ve güvenilir bilgi sağlamak, sadece sağlık çalışanları için değil, aynı zamanda genel nüfus için de enfeksiyonların bulaşmasını azaltmak için çok önemlidir" denilmektedir (Chan vd., 2020). Medya kuruluşlarından bilgi alan kitle için en büyük sorun, hangi habere güvenileceğinin bilinmemesi meselesidir. Haber, güvenilir olduklarına inanılan kaynaklardan gelip, "gerçekliklerinden" şüphe edilmeyen bilgileri içerir. Bu nedenle, yayınlamanın önünde "geleneksel yöntemler" açısından hiçbir engel bulunmamaktadır. Ancak, geleneksel ve sosyal medyada yanlış bilgilerin kapsamını ve sonuçlarını anlamak için daha fazla çalışmaya ihtiyaç duyulduğu açıktır. Sosyal platformlar yanlış bilgiyle mücadele için çaba sarf etmelerine rağmen, yanlış bilgilerin hala önemli sayfalarda ve gruplarda gösterilmeye devam etmesi eleştirilere neden olmaktadır (Kouzy vd., 2020). Yapılan çalışmalara rağmen günümüzde yanlış/eksik/yanıltıcı enformasyonun sosyal medya platformlarında nasıl dolaşıma girdiği, kişilerin tutum ve davranışları üzerinde ne kadar etkiye sahip olduğu cevabını bekleyen bir soru olarak kalmaya devam etmektedir. "Kullanıcıların yanlış bilgi yayan ağlarda tesadüfen gelen bilgilere maruz kalabileceği, yanlış bilgilere kümülatif maruziyet arttıkça, kullanıcıların aşinalıklarına 
daha güçlü bir inanca yol açan pekiştirme etkisi yaşama olasılığının yüksek olacağı" söylenmektedir (Dechene vd., 2010).

Bu bilgiler 1şı̆̆ında kamuoyu, kriz durumlarında "her türden bilgi"yi "hakikatin ifadesi" olarak kabul edebilir. Dolayısıyla okur ve izler kitlenin, kriz dönemlerinde ulaştığ1 haber ve bilgileri eleştirel bir süzgeçten geçirmesini beklemek gerçekçi bir yaklaşım olmaz. Krizler, kulaktan dolma söylentiler, propaganda veya manipülasyon amaçlı aktarımlar "bilgi kirliliği”"nin oluşmasına elverişli bir ortam oluşturmaktadır. Kriz ortamı aynı anda toplumsal infiale yol açabilir, karmaşalar doğurabilir. Bu durumlarda enformasyonun doğruluğunun sorgulanmasından çok, konuyla ilgili fikirler, yorumlar ve tartışmalar öne çıkmaktadır. Çaplı ve Taş (2010) bu dönemlerde değerlendirme ve yorumların bilginin geri plana atılmasına neden olduğunu söylemektedir. Panik halinde insan psikolojisini etkileyen duygu "korku"dur, korku aynı zamanda insanların hayatta kalmasını sağlar. İnsanlar korku ile karşı karşıya kaldıklarında bu duyguyu bulaştırmayı da başarır (Christakis ve Fowler, 2012: 48). Yapılan çalışmalar koronavirüs pandemisi de birey ve toplum psikolojisi üzerinde olumsuz sonuçları doğurmuş, özellikle kronik anksiyete ve stresör olmuştur (Kırık ve Orkan, 2021).

Kriz dönemlerinde habercilik pratiği ve habercilik etiği açısından bakıldığında, kriz dönemi haberciliğinin de medyanın toplumsal sorumluluğuyla birlikte şekillenmesi gerektiği ilkesi göz ardı edilebilmektedir (Christakis ve Fowler, 2012). Dünyanın sorunu haline gelen bir pandemi krizinin yaşandığı durumlarda her kesimden medya mensuplarının, habercilik pratiği içerisinde medyanın toplumsal sorumluluk kuramını daha fazla göz önünde bulundurması beklenmektedir. Kriz dönemleri medya açısından daha fazla okur ve izleyici elde etmek için bir firsat yaratsa da habercilik değerleri açısından bir tehdite dönüşmemelidir. Olağandışı koşullar haber alma ihtiyacını arttırmakta ve enformasyon akışı zaman zaman toplum açısından tehdit oluşturabilecek kaygan bir zemini sağlayabilmektedir. Üretilen enformasyon yeniden üretilebilme olanağı taşımakta ve sağlıklı akışın sağlanabilmesi açısından kamu yararı ve insani değerleri barındırması öncelik taşımaktadır. Özellikle insan hayatının söz konusu olduğu durumlarda bu iki kriterin önemi hayati değerdedir. Kırık ve Orkan (2021) "yanlış/eksik/yalan bilgilerin kontrolsüz bir biçimde yayılmasının kişide; gerçeklik algısının değişimi, gelecek beklentilerinde sapma, kararsızlık, endişe ve panik gibi kaygı bozukluklarına yol açtı̆̆ını" söylemektedir. Kitle iletişim araçları tarafından aldığımız enformasyon bilgi dünyamızı etkileyerek fikir beyanlarımızı şekillendirmekle birlikte, sağlık söz konusu olduğunda korku ve riske dair bakış açıları da değişmektedir. Yalnızlaşan ve yabancılaşan birey güvende kalmak endişesiyle hareket ederken yönlendirmeye daha açı hale gelmektedir (Furedi, 2001). Özellikle bulaşın insandan insana hareket ettiği salgın dönemlerinde bu durumun arttığ 1 ve geleneksel yaşamdan uzaklaşılarak içe kapanmanın sıklıkla gözlemlendiği söylenebilir.

\section{Covid-19 ve İnfodemi ile Mücadele}

Haziran 2021 itibariyle dünya genelinde 181 milyon doğrulanmış vaka ile 3,9 milyon ölü sayısına neden olan koronavirüs salgınıyla mücadele etmeye devam eden dünyada aynı zamanda sosyal ağlar üzerinden süren bir post-truth sınavı verilmektedir. 
Son yüzyılın en büyük sosyal krizi olarak da tanımlanan Covid-19 salgını sadece sağlık sistemleri açısından değil, hakikat ve doğru-yanlış bilginin sınavı açısından da tarihi bir dönüm noktasıdır. Dijital çağda haberin dolaşımından, habere erişime kadar alışkanlıkların değişmesi nedeniyle ortaya çıkan gerçek - yalan haber tartışmasının doğurduğu bir kavram olan "Post-truth", nesnel gerçeklerin; duygulardan ve kişisel inançlardan daha az etkili olma halini tanımlar. Kavram bu noktada, nesnel gerçekliğin önemsizleştirilmesi, bilgiye duyulan güvenin düşmesi olarak açıklanmaktadır. Günümüzde sosyal medyanın sağladığ 1 eşsiz imkanlar tam olarak yalan tam olarak da doğru olarak kabul edilemeyecek bilgilerin çok hızlı yayılmasına neden olmaktadır. Sosyal medyanın habere erişimde birincil kaynak olarak kabul edilmesinin etkisi post-truth döneminin en büyük handikabıdır. Olgu, bilgi ve inançların birbiri içerisine girerek gerçekten uzaklaşmayı tarif eren "hakikat sonrası siyaset" kavramı da 2016 ABD Başkanlık seçimleri ve Brexit sürecinde popülerlik kazanmış, toplumsal kanaatlerin artık gerçeklerden değil, şahsi fikirlerden oluştuğunu kanıtlanmıştır. Pew Research Center Amerikalıların yüzde 80'inin sağlık ile ilgili konuları internetten araştırdıklarını kanıtladıkları çalışmaları bu savı desteklemektedir (Fox, 2006). Reuters Enstitüsünün Dijital Haber Raporu'na göre (Newman vd., 2017), Türkiye'de bilgi almak için dijital kaynaklara başvurduklarını söyleyenlerin oranının yüzde 89 olarak çıkması da hakikat sonrası sürecin nasıl şekillendiğini göstermektedir (Newman vd., 2017).

Koronavirüs ilk olarak Aralık 2019'da Çin'in Wuhan kentinde görülmüş, hastalıkla ilgili bilinmezlik "virüsün Çinliler tarafından laboratuvar ortamında tasarlanmış bir biyolojik silah olduğu" gibi teoriler ortaya atılmıştır. Bu söylentiler dünya çapında hastalığın ciddiye alınmasını geciktirmiş, Dünya Sağlık Örgütü (DSÖ) Genel Direktörü Dr. Tedros, Şubat 2020'de "Biz sadece bir pandemiyle değil, aynı zamanda bir infodemiyle de savaşıyoruz" demiştir. İngilizce "information" ve "pandemic" sözcüklerinden türetilen infodemi, DSÖ tarafından "Covid-19'a yönelik gerçek dışı ya da hatalı bilgilerin yayılması, aşırı bilgi yükünün beraberinde güvenilir olmayan bilgileri getirmesi, yanlış bilgi epidemisi" olarak tanımlamıştır (WHO, 2020a). Eysenbach da 2002'deki çalışmasında edipemiyolojinin tanımından yola çıkarak, sağlıkla ilgili bilgilerin yanlış yayılımı olarak "infodemiyoloji” kavramını ilk kez dile getirmiştir (Eysenbach, 2002). $\mathrm{Bu}$ tanımlardan yola çıkarak infodeminin özellikle dünyanın tamamını ilgilendiren salgın durumlarında yanlış/eksik/yanıltıcı haberlerin toplum üzerindeki negatif etkilere odaklandığını söylemek mümkündür. Kendini koruma ve yaşama içgüdüsüyle hareket eden bireyler konu hakkında ihtiyaç duydukları enformasyonu medya kanalları aracılığıyla elde ederken, salgın dışındaki tehlikelere de açık hale gelmektedir. Bütün dünyayı ilgilendiren salgınların görüldüğü dönemlerde panik havasının yaratılmaması ve olası risklerin değerlendirilerek en düşük seviyeye çekilebilmesi açısından haber alma kaynakları, aracı konumunda görev almaktadır. Dolayısıyla bu durumlarda gündemi oluşturan kitle iletişim araçlarının sunduğu enformasyonun önemi artmakta ve bireylerin yaşam pratiklerini etkilemektedir.

Teknolojik gelişmelerin insan hayatına getirdiği yenilikleri göz ardı etmek mümkün değildir. Bireyler yaşamlarını kolaylaştıran her yeniliği hayatlarına kolayca almakta ve olanakları dahilinde kullanmaktadır. Ancak görülen odur ki sağlık söz konusu olduğunda yaşamakta olduğumuz enformasyon çağı bazı tehlikelere de açık hale gelmemizin 
önünü açmaktadır. Bu tehdidin büyüklügü ve getireceği sonuçlar tamamen bireysel tercihlerimiz çerçevesinde şekillenmekte ve telafisi olmayan sonuçlar doğurmaktadır. Fast ve Markuzon'a göre (2019) infodemikler endişe verici boyutlara ulaşmıştır çünkü yanlış veya yanıltıcı bilgilerin yayılması, iletim modellerini değiştirme kapasitesine ve sonuç olarak bir pandeminin ölçeğini ve ölümcüllüğünü değiştirme kapasitesine sahiptir (Kim vd., 2019).

Geçmişe bakıldığında insanlığın yaşamış olduğu salgınlar son derece trajik sonuçlar doğurmuş ve çok fazla insan hayatına mal olmuştur. Ancak günümüzde yaşanan salgını tarihsel hafızamızla tanımlamak doğru olmayacaktır. Günümüz ana akım medyası tarafından sunulan bilgi artık sosyal medya kullanıcıları tarafindan alıntılanarak dolayımlanmakta, bilginin şekil değiştirmesine ve bağlamından koparılarak aktarılmasına yol açmaktadır. Bununla birlikte sosyal medya kullanıcıları tarafından paylaşılan ve haber niteliği taşıdığı düşünülen haberler medya tarafından izleyiciye ulaştırılmakta ve bir kısırdöngüye neden olmaktadır. Sosyal medyada yaşanan bireysel ifadelerin getirdiği bilgi kirliliğinin oranı nedeniyle tarihte yaşanan salgınlarla günümüz salgınlarının kıyaslanması mümkün olmasa da dezenformasyona açık olmamız insanlık tarihine yayılmıştır. Dünyanın maruz kaldığı Ebola ve Zika gibi salgınlar döneminde de dezenformasyonu yaygın olarak görmek mümkündür. (Fung vd. 2016; Sharma vd., 2017) Yine bulaşıcı hastalık aşılarının da yanlış bilginin hızla yayıldığı başlıklar arasında yer aldığı Radzikowski ve arkadaşlarının çalışmasında görülür. (Radzikowski vd., 2016)

Medya aracılığıyla halk tabanına yayılan yanlış/eksik/yanıltıcı haberler uzmanların birbiri ile çelişen açıklamaları ile birleşerek bireyde korku ve paniği arttırmıştır. Salgın hızla ilerken, infodemi de hız kesmemiş, Whatsapp sohbetleri ve e-posta kutuları da sosyal medya platformları gibi çoğu doğru ve gerçek olan, ancak çoğu kullanılamaz bir bilgi çı̆̆ arasında boğulmuştur. Sosyal medyanın yaygınlaşması, bilimsel verilerin paylaşımında potansiyel olarak bilgilenme düzeyini artıran demokratik bir pencere olsa da kişisel fikirler yığını nedeniyle "güvenilirlik" derecesi olumsuz yönde etkilenebilmektedir. Beklenmedik bir hızda ve çeşitli mutasyonlar geçirerek ilerleyen salgınla birlikte infodemi de aynı performansı göstermekte ve yayılmaya devam etmektedir. Çin'in Aralık 2019'da ilk vakası ortaya çıkmasına rağmen, dünyaya yayılabilme olasılığı olan bir pandemi krizini geç görmesi ve haber akışı eksikliğinin neden olduğu kriz gibi birçok örnek bulunmaktadır. $\mathrm{Bu}$ durum Çin vatandaşlarına karşı bir negatif ayrımcılığa da sebebiyet vermiştir. Pandeminin başlangıcında Fransız Sağlık Bakanı Oliver Véran 14 Mart 2020 tarihinde Twitter hesabından "Antienflamatuar ilaçların enfeksiyonu kötüleştirdiğini" iddia etmiştir. Bu bilgi yalanlansa da sosyal medya aracılığıyla dolaşıma girmiş, bilgi aylarca tartışmaların odağında kalmaya devam etmiştir. 25 Şubat 2020 tarihinde yaptığ açıklamada İran Cumhurbaşkanı Hassan Rouhani koronavirüsü “İran'a yönelik yapılan bir düşman oyunu" olarak nitelendirirken (Stone, 2020), 10 Mart 2020 tarihli demecinde Brezilya Devlet Başkanı Jair Bolsonaro "virüsün bir fantezi olduğunu" söylemiştir (WHO, 2020b). Dünya Sağlık Örgütü ile ters düşen beyanlarda bulunan ABD Başkanı Donald Trump bu süreçte aşıya ve maske kullanımına karşı olduğunu ifade ettiği birçok açıklamayı dünya kamuoyu ile paylaşmıştır. Sahte haberler Japon halkının eczaneleri cerrahi maske satın almak için kuşatmasına yol açarken Brezilya'da ve İran'da binlerce kişinin temizlik ham maddesi içerek kendisini zehirlediği bilgileri medyaya yansıyan 
örnekler arasındadır (Llewellyn, 2020). Koronavirüsün en çok etkilediği ve araştırmalara göre çok yanlış söylentiye maruz kalan ülkelerden biri olan İran'da alkol tüketiminin yasak olmasına rağmen alkolün virüsü öldürdüğü söylentileri üzerine birçok insanı metanol ve deterjan içerek zehirlenmiştir. Amerika Birleşik Devletleri'nde salgının ilk aşamalarında gönderilen kısa mesajlar kaosa neden olmuş, Milli Güvenlik Kurulu, bölge sakinleri arasındaki korku ve paniği azaltmak için harekete geçmiştir. Sıcak su, yılan yağı veya gümüş içmenin ve tütsü yaprakları yakmanın koronavirüsü tedavi edeceği iddiaları popüler hale gelmiştir (Brewster, 2020). Amazon'un koruyucu maskeler için yürüttüğü reklamlar, dünya çapındaki tıp camiasının malzemeye çok ihtiyaç duyduğu zamanlarda fiyatları ve tıbbi ekipman istifini artırmıştır (Palmer, 2020). Pek çok sosyal medya hesabı, biyolojik bir silah olarak tanımladığı virüs ile ilgili komplo teorileri ile vitamin ve benzer ürünleri satın almaya yönlendirmiştir (Marantz, 2020). Hücresel veri ağlarını destekleyen bir kablosuz iletişim teknolojisi olan 5G'yi yanlış bir şekilde Covid-19'a bağlayan gönderiler de geniş çapta yayılmıştır (O’Donnell, 2020). Aşı karşıtı hareketler, izlenme ve takipçilerde artış sağlamak için aşılara karşı sosyal medya hesaplarını kullanmıştır. Tam da beklendiği üzere bu dezenformasyon dünyada virüse inanmayan, yok sayan, hatta aşı karşıtı olarak nitelendirilen bir kitle oluşturmuş, bu inanış hızlıca kendisine binlerce taraftar bularak sosyal medya kanalları aracılığıyla yayılmıştır. Kendilerine aşı yoluyla "çip" takılacağını düşünen ve aşı karşıtlığı kampanyasını yürüten kişi sayısı arttıkça korku toplumunda yaşayan bireyin içsel çelişkilerini görmek de kolaylaşmaktadır. İnsanların salgın sırasında hastalıkla ilgili bilgileri öğrenmek ve virüsün etkisini azaltmak için gösterdiği ilgiyi fark edenler, salgının gidişatı ve tedavisi ile ilgili söylentiler de yaymıştır. Bunlar arasında en çok virüsün çocukları enfekte edip etmediği, bazı sıcaklık derecelerinin üzerinde yaşamadığ 1 , belirli bir besin ya da diyet yönteminin tedavi edici olduğu gibi asılsız haberler sıkça yayınlanmıştır.

Örnekler sayısız ve sınırsız alana yayılabilir. TRT Akademi İnfodemi Araştırması Raporu (2020) teyitsiz ve bilimsel olmayan bilgilerin birçok medya kuruluşu tarafindan paylaşıldığını, Facebook ve Twitter gibi sosyal medya platformlarının da etkisiyle erişimi arttırdığını göstermektedir (Geçer, 2020). Zira Mitchell ve arkadaşlarının yaptığ çalışmalar (2016) da göstermektedir ki günümüzde sosyal platformlar, birincil haber kaynaklarına olarak giderek daha fazla güvenilmektedir. Garrett ve arkadaşları da (2016) "yanlış bilgilerin yoğun şekilde bu platformlar aracılığıyla yayıldığı açıkça görülmektedir" demektedir. Bu noktada üzerinde durulan sosyal medyanın ortaya çıkışından bu yana haber üretimi, dağıtımı ve tüketiminin değiştiği gerçeğidir. Dijital 2020 raporuna göre "2019' da tahmini 2,95 milyar kişinin dünya çapında sosyal medyayı kullandığı hesaplanırken, bu sayı Covid-19 pandemisi döneminde 4 milyar bandını geçmiştir” (Kemp, 2020).

Pandemi döneminde insanlar sahte haberlerin yaygın hale geldiği bir "infodemik" dünyada yaşamak zorunda kalmıştır. Salgının yaygınlaşması, medyanın bir anlamda tsunamisi ile sonuçlanmış, çoğu platform, çoğunlukla salgın ile ilgili haberleri, yönergeleri ve önlemleri insanlara iletmek için ağını kullanmış olsa da kontrolsüz bilgi akışı, komplo teorileri ve propagandalar salgınının kendisinden daha hızlı yayılmıştır. 2020 'de koronavirüs ve Twitter etkisini inceleyen araştırmacılara göre "yaratılan bu infodemik ortam psikolojik paniğe, yanıltıcı tıbbi tavsiyelere ve ekonomik bozulmaya neden olmuştur" (Mourad vd. 2020). 
Salgının gelişim ve değişimi konusunda toplumun artan haber alma ihtiyacı esnasında yayılan yanıltıcı bilgiler nedeniyle hala şüpheyle yaklaşılan birçok belirsiz alan bulunmaktadır. Bireyin birbiri ile çelişen yüksek miktarda enformasyona maruz kalması durumunda bilgiyi yok sayma tehlikesi göz önünde bulundurulduğunda durumun önemi daha açık ortaya çıkmaktadır. Çelişkilerin "sıradan" olarak görülmesi ve içselleştirilmesi, hayatın olağan akışı haline gelmesi büyük tehlikeleri de beraberinde getirmektedir. Kaygı ve endişe ile başa çıkmakta zorlanan birey, uzman bir yardım almadığı sürece bu kaygılardan uzaklaşma ne normal hayatına dönme ihtiyacı hissetmektedir. Özellikle salgın dönemlerinde bu durumun toplumun psikolojik durumu üzerinde etki yarattığ uzmanlarca da dile getirilmektedir. Erzurum Atatürk Üniversitesi Tıp Fakültesi Araştırma Hastanesi Ruh Sağlığı ve Hastalıkları Ana Bilim Dalı Öğretim Üyesi Doç. Dr. Halil Özcan, pandemi döneminde kaygı, anksiyete bozukluğu ile depresyon yaşayanlarda artış gözlendiğini açıklamıştır (A Haber, 2020).

Sonuç olarak, resmi kuruluşlar, hükümetler ve iş dünyası liderleri, sahte haber fırtınasını azaltmak için sosyal medya platformlarına yönelik çeşitli yöntemler geliştirmiştir. $\mathrm{Bu}$, karantina ya da izolasyon altındaki milyonlarca kişinin doğru ve tıbbi olarak sağlam bilgiler almasını sağlamak için bir öncelik haline gelmiştir. Sosyal medya kuruluşları, zararlı içeriğin tanımlanması ve yasaklanması üzerinde kontrole sahip olduklarını iddia etseler de çok geçmeden aslında krize iyi hazırlanmadıkları ve infodemiye yanıt vermek için acil durum planlarına ihtiyaç duydukları ortaya çıkmıştır. Virüsün hızla yayılmaya başladığının ortaya çıktığı Şubat 2020 tarihide ilk kez dillendirilmeye başlayan "infodemi” mücadelesinin tüm ülkelerde uygulanmasının ve merkezi konumda olmasının önemini duyuran DSÖ Sağlık Örgütü Risk İletişimi Ekibi tarafından Salgın Bilgi Ağı (EPI-WIN) oluşturulmuş ve pandemi ile ilgili tüm mesajların izlenmesine, kanıta dayalı bilgilerin yayılmasına ilişkin kurallar belirlenmesine karar verilmiştir. Birleşmiş Milletler Yardım Fonu (UNICEF) ve Uluslararası Kızılhaç ve Kızılay Dernekleri Federasyonu (IFRC) doğru bilgilerin yayılımı ile mücadele başlattı, risk iletişimi ve toplum katılımı ile ilgili rehberler yayınlanmıştır (WHO, 2020c). Mart 2020 tarihinde DSÖ, Whatsapp ve Facebook ile kurduğu ortak platformda pandemi ile ilgili son haberlerin yayınını sağlamıştır. Nisan 2020'de ise yanıltıcı sağlık ürünlerinin satışını engellemek ve yayınına ilişkin önlem almak amacıyla "Tıbbi Ürün Uygulaması” başlatılmıştır. Aynı ay DSÖ, “Covid-19 İnfodemisinin Yönetilmesi” başlığı altında düzenlediği toplantıda ana prensipleri açıklanmıştır:

1- Müdahaleler ve mesajlar kanıta dayanmalıdır.

2- Bilgi, toplumların tüm sektörleri tarafından eri ilebilecek şekilde sunulan, eyleme geçirilebilir davranış değişikliği mesajlarına dönüştürülmelidir.

3- Hükümetler, kilit topluluklara ulaşarak toplumun endişelerini ve bilgi ihtiyaçlarını anlamalı, bu şekilde tavsiyelerini ve mesajlarını uyarlamalıdır.

4- Stratejik ortaklıklar, akademi ve sivil toplum kuruluşlarının yanı sıra sosyal medya ve teknoloji platformları ile de kurulmalıdır (WHO, 2020d).

DSÖ ve Uluslararası Telekomünikasyon Birliği (ITU) bu prensiplerden yola 
çıkarak, doğru bilgilerin yayılması için mesaj kütüphanesi kurmuş ve halkın kullanımına açmıştır. Haziran 2020'de 1. İnfodemiyoloji Konferansı'nı düzenleyen DSÖ, infodemi ile mücadele için gerçek temelli mesajların yayılmasının önüne geçmek için ahlaki değerlerin dikkate alınması gerektiği mesajlarını vurgulamıştır.

Türkiye'de de uzman sağlık habercilerinin üye olduğu ESAM Yönetim Kurulu aşılamayı baltalayabilecek yanlış haberler ve yorumlarla ilgili Ocak 2021'de uyarı yayınlamıştır. ESAM açıklamasında, "Yanlış bilgi, virüsün ve salgının kendisinden çok daha öldürücü olabiliyor. Salgın, uzman muhabirliğin önemini ve gerekliliğini bir kez daha ortaya koymuştur" denilmiştir (Cumhuriyet, 2021).

Pandemi gibi olağanüstü süreçlerde gerçek ve sahte ayrımı ortadan kalkmaya başlamış, dezenformasyon ve infodemi kitleleri tehdit eder hale gelmiştir. Bu nedenle bilime dayalı ve objektif habercilik günümüzde her zamankinden çok daha önemlidir. Yanlış bilgi ve komplo teorilerinin medya aracılığıyla toplumun geniş kesimlerine erişmesinin önüne geçilmelidir.

\section{Araştırma}

\section{Amaç, Yöntem, Örneklem}

Çalışmanın amacı Covid 19 salgını sürecinde infodeminin yayılmasına kaynaklık eden mecralar ve gazetecilik pratiklerini uzman görüşleri doğrultusunda belirleyerek, infodeminin önlenmesine yönelik öneriler geliştirmektir. Bu doğrultuda araştırmanın soruları şöyledir:

- Sağlık habercileri infodeminin yayıldığı mecralara ilişkin görüşleri nelerdir?

- Sağlık habercilerine göre Covid 19 salgınında yanlış bilginin üretilme amacı nedir?

- Sağlık habercilerine göre Covid 19 pandemisinde en fazla yanlış bilgi hangi haber kategorilerinde görülmüştür?

- Sağlık habercilerinin infodeminin önlenmesine ilişkin önerileri nelerdir?

Araştırmanın yapılabilmesi için İstinye Üniversitesi Sosyal ve Beşeri Araştırmaları Etik Kurulu'ndan izin alınmıştır (Sayı: 2021/09, Karar No: 1, Tarih: 10.06.2021). Çalışmanın soruları ve amacı doğrultusunda, amaçlı örnekleme ile belirlenen dokuz sağlık gazetecisi ile derinlemesine görüşmeler gerçekleştirilmiştir. Çalışmanın örneklemini sağlık alanında uzun yıllara dayanan deneyimi olan sağlık muhabirleri oluşturmaktadır. Çalışma kapsamında; Eğitim ve Sağlık Muhabirleri Derneği Yönetim Kurulu Üyesi, Sağlık Editörü, ScienceUp Yazarı Ayşegül Aydoğan Atakan, TVnet Sağlık Yapımcısı/ Sunucusu ve Hospital Manager Dergisi Yayın Kurulu Üyesi Ayşenur Asuman Uğur, TRT Sağlık Muhabiri ve Editörü Fatma Demir Turgut, ATV Haber Muhabiri ve Spikeri Iş11 Açıkel, NTV Sağlık Editörü Melike Şahin, Milliyet Gazetesi Sağlık Editörü Meltem Günay, Eğitim ve Sağlık Muhabirleri Derneği Yönetim Kurulu Üyesi, Sağlık Editörü Mesude Erşan, TGRT Haberi Sağlık Editörü Özay Erad ile isminin gizli tutulmasını isteyen bir gazeteci ile görüşülmüştür. Amaçlı örnekleme yöntemiyle konuyla ilgili zengin bilgiye sahip olduğu düşünülen ve pandemi döneminde infodemiye karşı öneriler 
geliştirebilecek deneyimi bulunan özel bir gruba ulaşılması hedeflenmiştir. Çalışmada veri toplama aracı olarak yarı yapılandırılmış görüşme tekniğine başvurulmuştur. Elde edilen veriler bilgisayar destekli nitel veri analizi programı NVIVO 12 aracılığıyla içerik analizine tabi tutulmuştur. Veriler iki araştırmacı tarafından ayrı ayrı kodlanmış ve aralarındaki uyum katsayısı yüzde 97 bulunmuştur. Bulgular 7 ana tema ve 41 alt kategori altında toplanmıştır.

Kodlamalara ilişkin ana kategoriler Demografik Veriler, Haberin Yayıldığı Mecraya İlişkin Görüşler, Yanlış Bilginin Kaynağına İlişkin Görüşler, Haberin Yapılma Nedenine İlişkin Görüşler, Yalan Haber Kategorilerine İlişkin Görüşler, Yanlış Bilginin Yayılmasında Sorumluluğa İlişkin Görüşler, Önerilere İlişkin Görüşler başlıkları altında toplanmıştır.

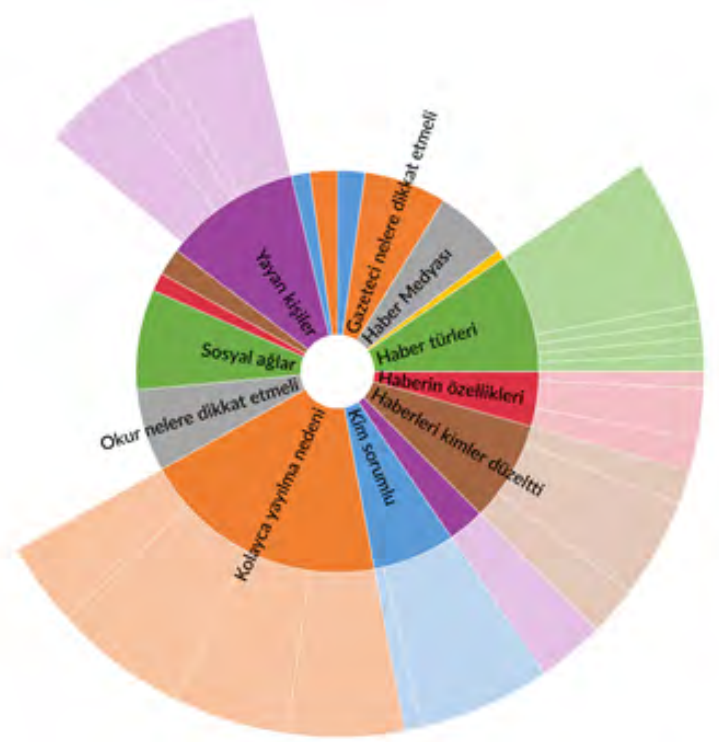

Grafik 1. İçerik Analizi Kapsamında Kodlanan Temalara İlişkin Hiyerarşi Şeması

\section{Bulgular}

\section{Demografik Özellikler}

Derinlemesine görüşülen gazetecilerin sağlık haberciliği alanındaki tecrübeleri 8 ile 25 yıl arasında değişmektedir. Katılımcıların yaş, habercilik ve sağlık haberciliği deneyimleri aşağıda yer alan Tablo 1'de gösterilmiştir.

$\begin{array}{llll}\text { Katılımcı } & \text { Yaş } & \begin{array}{l}\text { Habercilik } \\ \text { Deneyimi }\end{array} & \begin{array}{l}\text { Sağlık Haberciliği } \\ \text { Deneyimi } \\ \text { Işıl Açıkel }\end{array} \\ \begin{array}{l}\text { Ayşenur } \\ \text { Asuman Uğur }\end{array} & 42 & 23 & 10 \\ \text { Fatma Demir Turgut } & 40 & 15 & 15 \\ \text { Ayşegül Aydoğan Atakan } & 40 & 20 & 15 \\ & 46 & 26 & 25\end{array}$




$\begin{array}{llll}\text { Mesude Erşan } & 52 & 30 & 25 \\ \text { Melike Şahin } & 32 & 9 & 8 \\ \text { Meltem Günay } & 44 & 24 & 16 \\ \text { Özay Erad } & 56 & 38 & 19 \\ \text { Gazeteci X } & - & 27 & 22\end{array}$

Tablo 1. Katılımcılara İlişkin Demografik Veriler

\section{Haberin Yayıldığı Mecraya İlişkin Görüşler}

İnfodeminin yayılmasında etkili olan mecraları belirlemek üzere gazetecilere yanlış bilgi içeren haberlerin yayıldığı mecralar sorulmuştur. Buna göre infodemide etkili olan mecralar sağlık habercilerine göre en fazla sosyal ağlar ve anlık mesajlaşma servisleridir. İkinci sırada ise internet haber siteleri ile TV kanalları infodeminin yaygınlaşmasında etkili olmaktadır.

Görüşülen sağlık habercilerine göre Covid-19 salgını sürecinde infodemiyi tetikleyen haberler en fazla Twitter, Facebook gibi sosyal ağlar, anlık mesajlaşma servisi Whatsapp ve arama motoru Google' da yayılmıştır. Gazetecilerin konuya ilişkin görüşleri aşağıda aktarılmıştır:

Işıl Açıkel: Sosyal medyada Twitter'da ve anlık mesajlaşma ortamı Whatsapp'ta infodemi çı̆̆ gibi büyüyor.

Ayşenur Asuman Ŭ̆ur: Yanlış bilgiye en çok sosyal medyada, sonra da TV ve video içeren haberlerde rastllyoruz. Yazılı haberlerde görece daha temkinli bilgi aktarıldı ̆̆ını düşünüyorum.

Fatma Demir Turgut: Bu haberlerin yayılmasında Twitter ve Whatsapp'ın başı çektiğini düşünüyorum. Whatsapp'ta salgının başında bir anda binlerce insana ulaşan ses kayıtların herkes hatırlar.

Ayşegül Aydoğan Atakan: Bu haberler haber siteleri ve sosyal ağlar dışında en çok Whatsapp yoluyla dolaşımda kalabiliyor. Herhangi bir yanlış veya çarpıtılmış bilgi diğer mecralara göre özellikle Whatsapp’taki gruplar aracılı̆̆lyla daha kitlesel ve kolay yayılma imkanı buluyor.

Mesude Erşan: Facebook, Twitter gibi ortamlar bu tür bilgilerin yayllması için ideal ortam görevi görüyorlar. Haftada en az bir kez, 'pandeminin yalan' veya 'aşının zararlı ve gereksiz'olduğu yönündeki paylaşımlar TT oluyor.

Meltem Günay: Başta Twitter olmak üzere aslında tüm sosyal ăglar bu tür haberlerin çıkış ve yayılış noktası. Yine Whatsapp grupları bu tarz haberlerin yayılmasında etkili.

Gazeteciler haber medyasının ise sosyal ağlara göre yanlış haberlerin yayılmasında daha az etkili olduğu görüşündedir. Haber medyasında, sosyal medyaya göre daha az olmakla birlikte öncelikle dijital haber platformlarının, daha sonra TV kanallarının infodeminin yayılmasında rol aldığını söylerken, yazılı basının bu konuda daha dikkatli bir 
yayıncılık yaptığını belirtmişlerdir. Melike Şahin, Meltem Günay, Özay Erad ve Gazeteci $X$ haber medyası içinde yanlış bilginin en fazla yayıldı̆̆ mecranın internet haber siteleri olduğunu belirtmiştir.

Iş1l Açıkel, "Geleneksel medya dışında dijital platformda infodemi daha yaygın. Geleneksel medya, halkın sağlı̆̆ını da göz önünde bulundurarak haberleri süzgecinden geçirerek ekrana yansıttı" derken, Fatma Demir Turgut ise şu görüşleri paylaşmıştır:

"Koronavirüs sürecinde infodemi içeren haberlerin en çok internet sitelerinde yer aldığını gördük. Salgının başlangıcında buna TV'lerin de dahil olduğunu söyleyebilirim. İleyicisi bol ama bilimsellikten uzak bazı uzmanların salginla ilgili sarf ettikleri halkı yanıltıcı bilgiler TV'lerde de yer aldı."

Mesude Erşan de hemen her mecrada infodemi içeren içeriklere rastladığını belirterek "Gazetelerin basılı tarafiyla, web tarafindaki farklılıklara da dikkatinizi çekmek isterim. Basılı nüshasında haber doğru yer alırken, web ortamında başlıkta dahi, tık uğruna ciddi çarpıtmalar gözlüyorum” demiştir.

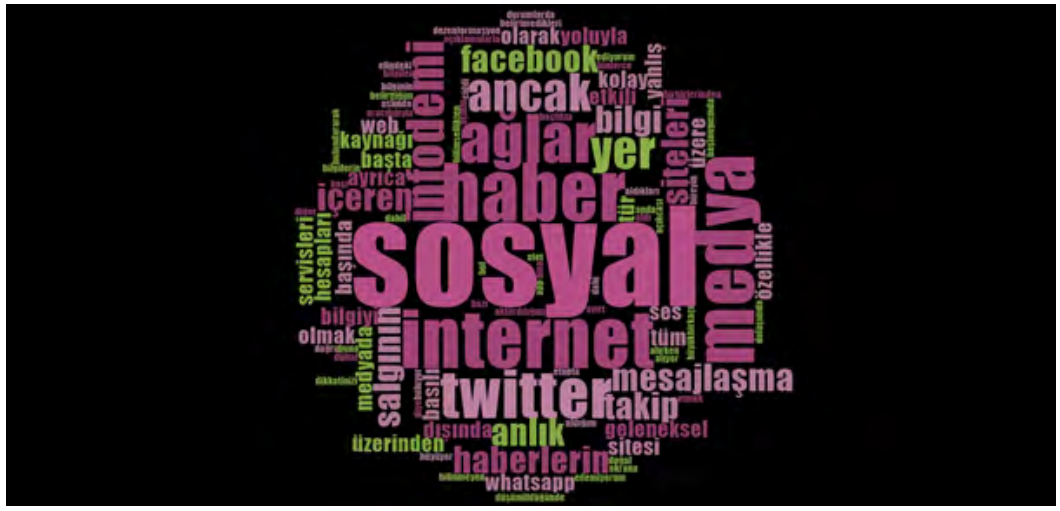

Grafik 2. Kelime Bulutu Gazetecilerin İnfodemi Sürecinde Sağlık Haberciliğinin Rolüne İlişkin Görüşleri.

Gazetecilerin "Yanlış Haberin Yayıldığı Mecraya İlişkin Görüşleri”, Nvivo Pro 12'ye kodlandiktan sonra "Kelime Bulutu” olarak görselleştirilmiştir. Kelime bulutu gazetecilerin konuya ilişkin yanıtlarında frekansı en yüksek kelimeleri göstermektedir. Kelime Bulutu 1'de de izlendiği gibi yanlış bilgi içeren haberler sosyal medya, sosyal ağlar Facebook ve Twitter'da ve anlık mesajlaşma servislerinde yayılmaktadır.

Sağlık habercilerinin yanlış bilgi içeren haberlerin yayıldığı mecraya ilişkin görüşleri bir arada değerlendirildiğinde, sosyal ağların ve Whatsapp'ın yanlış bilgi içeren haberlerin yayılmasında ana kaynak olarak görüldüğü tespit edilmiştir. Dijital medya ve TV kanalları gibi haber medyası da bu süreçte kötü bir sınav vermiştir. Gazeteciler yazılı basını ise bu süreçte daha güvenilir bir kaynak olarak değerlendirmiştir.

\section{Yanlış Bilginin Kaynağı}

Sağlık habercilerine yanlış bilginin kaynağı da sorulmuştur. Twitter, Facebook gibi 
sosyal ağlarda, Whatsapp gruplarında ve haber medyasındaki haberlerde dolaşıma giren bu bilgilerin kimler tarafından üretildiği sorusuna yanıt aranmıştır. Sağlık habercilerine göre yanlış bilgilerin önemli bir kısmında haberin kaynağı belirsizdir. Gazetecilerin konuya ilişkin görüşleri şöyledir:

Fatma Demir Turgut: Infodemideki bu haberlerin belirgin karakteristikleri çoğunun kaynaklarının olmayışı. Olanların da şüpheli kaynaklar oluşu.

Ayşegül Aydoğan Atakan: Ĕger haber kaynă̆l gösterilmiyorsa, örneğin ABD’deki bir çalışma (hangi çalışma ne zaman yapılmış veya yayımlanmış, hangi üniversite yapılmış vs) diye verilen bir haberde bu detaylar içerikte yoksa bu haberden şüphe duyulması gerekir. Să̆lık okuryazarlı̆̆ı açısından en önemli kural haberin kaynă̆ıdır. Salgın boyunca ama özellikle son dönemde aşı haberleri konusunda çok belirgin ortak özelliğe sahip yanlış haberler gözlemledik.

Melike Şahin: Bence en büyük ortak özellikleri güvenilir bir kaynaklarının olmaması. İkinci ortak özellikleri ise yanlış bilgi içeren haberlerin çoğuna genelde sansasyonel açıllamalarda bulunan uzmanların konuşuyor olması.

Melike Şahin: Aslında bu soruya salgından önce tanınmış kişilerin paylaşmasıyla yanlış bilginin daha hızl yayıldığı yönünde cevap verebilirdim. Fakat bence salgın bu konuda da bizi şaşırtmayı başardı. Kimden geldiği belli olmayan ses kayıtları, imzasız anonim bilgilerin kaynă̆ı sorulmaksızın sosyal medya uygulamalarında hızla yayıldı. Dezenofrmasyonların birçoğunun kaynağı "bir arkadaşımın arkadaşı" oldu bu süreçte. O nedenle bence tanınmış ya da tanınmamış birinin paylaşması değil de inanılmak istenen şeyin paylaşılmasi yayılmada etkili oldu.

Sağlık habercilerinin sosyal ağlardaki yanlış bilgilerin yayılmasında "kim"lerin etkili olduğuna ilişkin soruya verdikleri yanıtlar ise çarpıcıdır. Gazeteciler, yanlış bilgilerin yayılmasında en fazla konunun uzmanı olmayan hekimlerin yaptıkları paylaşımlar ile bu hekimlerin verdiği yanıltıcı içerikleri yine sosyal medya hesaplarında paylaşan gazeteci, siyasetçiler, fenomenler ve içerikleri sorumsuzca paylaşan diğer sosyal medya kullanıcılarının etkili olduğuna işaret etmektedir. Yanıltıcı ve sansasyonel bilgiler paylaşan hekimlerin uzman adı altında ekrana çıkarılması da gazetecilere göre infodemi de etkili olmuştur.

Gazetecilerin konuya ilişkin görüşlerinden bazıları şöyledir:

Ayşegül Aydoğan Atakan: Pandemi özelinde bakarsak bunu doktorların kişisel hesaplarından 'güya araştırma sonuçları'nı analiz ettikleri yorum ve sözde bilgilendirmelerle yaptıklarını gördük. Kimi zaman da merkezi otoritenin sakladı ̆̆ - paylaşmadiğ veriler üzerinden üretilen (tahminle ya da farklı bilgi kaynakları baz alınarak) hatal veri ve istatistikler de sağllk alanında uzman olmayan habercilerin yanlış haber yapmasına neden oldu. Kasıtlı olarak bu bilgileri üreten insanlar arasında da doktorlar dahil her meslekten - gruptan insanları bulabilirsiniz.

Melike Şahin: Bunu (infodemiyi) hep birlikte yaptık. Haberinin tıklanmasını isteyen bazı haberciler, şov yapmaya çalışan, alanı olmadığı halde konuşan doktorlara 
yer vererek yaptı bunu. Takipçi derdine düşen fenomenler sosyal medya hesaplarından yaptı, doğruluğunu araştırmadan bir yerde duymayı yeterli gören ünlüler yüzbinlerce takipçisiyle paylaşarak yaptı, tanınır olmak isteyen bazı doktorlar da sözlerini kimin nasıl algılayabileceğini düşünmeyerek yaptılar...

Ayşegül Aydoğan Atakan: Burada gazetecilerden çok politikacılar da infodemi açısından kötü bir karne verdi diyebiliriz. ABD, Ingiltere, Rusya gibi büyük devletler başta olmak üzere ülkemizde de sosyo - kültürel altyapının müsait olmast, bu haberlerin hem yapılma hem de yayılma nedenidir aynı zamanda.

Gazetecilere göre yanlış bilgi içeren haberlerin tanınmış ya da tanınmamış kişiler tarafından sosyal medya hesaplarında paylaşılması da yayılmalarında etkili olmaktadır.

Sansasyonel, aykırı bilgilerin her zaman dikkat çektiğine işaret etmektedir. Fatma Demir Turgut, "Az takipçili hesaplardan paylaşıldı̆̆ında bile bir anda milyonlara ulaşabildiğini görüyoruz. Ama tabi ki, çok takipçili tanınmış şarkıcı, oyuncu, sporcuların paylaşması çok daha etkili olabiliyor. Üstelik şöyle bir tehlike de var; bu kişilerin paylaştıkları büyük bir kesim tarafından onaylanıyor ve doğru kabul ediliyor. Çok daha fazla zarar veriyor" yorumunu yapmıştır.

Meltem Günay da "özellikle son dönemde fenomen diye tanınan kişilerin bazı eksik ve yanlış bilgileri kendi sosyal medyalarından paylaşmalarının bir anda bu tarz haberlerin binlerce kişiye ulaşmasına neden olabildiğini" hatırlatmaktadır.

Gazeteciler, infodemiye yol açan içeriklerin çoğunlukla kaynağı belirsiz olduğu görüşündedir. Gazetecilerin, kaynağın belli olduğu yanlış içeriklerin uzmanlık alanı olmayan ya da sansasyonel bilgi paylaşarak ilgi çekmeyen isteyen hekimler tarafından üretildiğini düşünmesi dikkat çekicidir. Bu içerikler ise gazeteciler, fenomenler, ünlü kişiler ile yakınlarını uyarmak isteyen sosyal medya kullanıcıları tarafından tekrar paylaşılmasıyla yayılmaktadır.

\section{Haberin Yapılma Amacına İlişkin Görüşler}

İnfodemiye yol açan Covid 19 salgınına ilişkin yanlış bilgi içeren haberlerin üretilme nedeni, sağlık habercileri tarafından üç ana kategoride değerlendirilmiştir. Bunlar yanlış bilgiyi kontrol etmeden, bilinçsizce haberleştirme; takipçi kazanma amaciyla üretme, kaos yaratmak ve oluşan durumdan beslenmek amacıyla kasıtlı olarak üretmedir.

Yanlış bilgilerin bilinçsizce yayıldı̆̆ını düşünen gazetecilerden bazılarının konuya ilişkin görüşleri şöyledir:

Ayşenur Asuman Ŭ̆ur: Bence bu süreçte aydın ve güvenilirdir dediğimiz insanların cehaletini de biraz gördük. Kötü niyetli olmasalar dahi, inandıklarını söylemeleri bile bilgi kirliliğine neden olup yanlış bilgilerin güvenilir bilgi olarak algılanmasına neden oldu.

Mesude Erşan: Bu bilgileri üretenler bence yanlış olduğunu düşünmüyorlar ve gayet ciddiler. Dolastyla böyle bir sorumluluk da hissetmiyorlar. Analiz yapamamak büyük sorun. Hoş analiz yapabilmek için de farklı kaynaklardan, çok fazla bilgiye sahip 
olmak gerekir.

Gazeteci X: Bilinçsizce yapılan ama zarar verebilecek haber üretildi. Tanıdıklarını bilgilendirmek isteyen sıradan insanlar yanlış bilgilerin yayılmasında etkili oldular.

Bazı gazeteciler, yanlış bilgilerin ilgi çekip takipçi kazanmak ya da rating ile tıklanma oranlarını artırmak amacıyla üretildiğini belirtmektedir. Bu görüşlerden bazıları şöyledir:

Işıl Açıkel: Yanlış bilgilerin üretilmesinde takipçi kaygısı var. Kurum ya da kişilere zarar vererek halkl, paniğe götüren dikkat çekici içerikler sosyal medyada paylaşılırsa takipçi sayısını artırıyor.

Melike Şahin: Birçok site yalnızca tıklanmak üzere içerik hazırlıyor. Yanlış bir bilgiyi bile bile dahi verebiliyorlar. Haber kanallarının çoğunun bile isteye yanllş bilgi içeren haber yapacağını düşünmüyorum. Ancak yeteri kadar araştırllmadan, hassasiyet göstermeden, alanında uzman kişiden görüş alınmadan yapılan haberlerin olduğunu maalesef görüyoruz.

Bazı gazeteciler, yanlış bilgilerin kasıtlı olarak üretildiğini düşünmektedir:

Ayşenur Asuman Ŭgur: Bu bilgileri üretenler kesinlikle muhabirler değil. Sosyal medyadaki kişisel hesaplar, kasitlı olarak bilgi üreten insanların bilgi kirliliği oluşturduğuna inaniyorum.

Fatma Demir Turgut: Siyasete alet edilebiliyor. Korku, panik yaratma amacı taşıyabiliyor. Tıklanma sayısını artırma amaçlanabiliyor.

Özay Erad: Amaç bir kaos ortamı oluşturmak bence. Kaostan beslenen bir grup var galiba. Insanları panikletmek, bunalıma sokmak gibi. Aslında bu da bir başka hastalık. Yani siz hastalıkla mücadele içindeyken farkında olmadan ikinci bir hastalıkla mücadele ediyorsunuz.

Işıl Açıkel: Infodemi, 'sahte haber sorunu'na yeni bir boyut kazandırdı. Kasıtlı olarak bilgiler üretiliyor ve sahte belgeler, sahte hesaplardan kolayca herkese. Hatta kimi yayın organları da bu tuzağa düşerek bilgiyi yazılı ve dijital sayfalarına taşıyabiliyor.

Özetle, bilinçsizce paylaşım, kaos yaratmak, takipçi/beğeni kazanmak, sağlık habercileri tarafindan infodemide yanlış bilgi üretiminin temel amaçları olarak değerlendirilmiştir.

\section{Yalan Haber Kategorilerine İliş̧kin Görüşler}

Sağlık habercilerine Covid 19 pandemisi sırasında yanlış bilgi içeren en fazla haberin hangi kategorilerde yapıldığı sorusu yöneltilmiştir. Gazetecilere göre infodemiye yol açan en fazla yalan haber aşı ve maske konusunda üretilmiştir. Gazeteciler Covid 19'un ortaya çıkışı, vaka sayıları, takviye gıdalar ve Covid 19'dan korunma yöntemleri 
ile ilgili de yanlış bilgi içeren haberlerin üretildiği görüşündedir.

Gazetecilerin konuya ilişkin görüşleri şöyledir:

Işıl Açılkel: En çok yanlış bilgilendirme aşı ve resmi açılklamalar konusunda oluyor. Aşı çalışmalarında MRNA aşılarının genlerimizi değiştireceği ve Türk halkının soyunu bitireceği haberler hesaplar arasında dolaştı. Kişi kendine yakın bulduğu açıklamaya çok çabuk inaniyor.

Ayşenur Asuman Ŭ̆ur: Başından beri maske meselesi bence önde gitti. Maskenin takılıp takılmayacă̆ meselesi aslında kamuoyu nezdinde ve bilim dünyasında ve meslek birliklerinde güvenilir insanların tartışması bence bilim ve tıp dünyasının ayıbıdır. Bilgi kirliliğini önce sağlık çalışanları klsmen başlattı. Bundan güç alan hem iyi niyetli olmayan ya da popüler olmak ve pandemi dolayısıla kendine alan açmak isteyen insanlar da halk să̆liğ aleyhine topluma mesaj verdiler.

Fatma Demir Turgut: En çok aşı ile ilgili bilgi kirliliği var maalesef. Dünyada yükselen aşı karşıtllğg trendi vardı. Salgında aşılar gündeme gelince akıl almaz bilgiler dolaşmaya başladı. En korkuncu da pandemi yok diyenler. Aslında salgın yok, hepsi aldatmaca diyebiliyorlar ve sosyal medyada TT olabiliyor. Biri kuzenimi ve amcamı kaybettim yine de inanmıyorum diye yazmış sosyal medyada. Çok patolojik bir durum.

Melike Şahin: Salgın zor bir süreç ve uyulması gereken zor kurallar var. Herkesin hayatından fedakarlıklar yapması gerekiyor. Bu nedenle insanlar bu zor kuralların aslında gerekmediğine dair "kolaylaştıran", inanmak istedikleri bilgileri veren insanlara inanmayı tercih ettiler. Bir de salgına inanmayı "gripten de bu kadar kişi ölüyor" iddiası taraftarları var ki, onlar da medyanın haberlerle korku yarattı̆̆ını iddia ettiler hep.

Ayşegül Aydoğan Atakan: Şu vitamin iyi mi - kötü mü haberleri yapıldı. Şu takviye korona'dan koruyor - hayır tam tersi korumuyor daha da kötüleştiriyor! Kelle paça koronasavar mı? Tuzlu gargara virüsün vücuda girmesini engelliyor mu?.. Bu minvalde haberler ve bilgiler de bizi şaşırtan örneklerden bazılarıydı.

Mesude Erşan: Pandeminin başından beri vaka ve kayıplarla ilgili bilgilerin siyasi otorite tarafindan gizlenmesi çok güven sarsıcı oldu. Siyasi erk gerçeği saklayınca, aşılarla ve korunmayla ilgili diğer talepler de kuşkuyla karşılanabiliyor.

\section{Yanlış Bilginin Önlenememesinde Sorumluluğa İlişkin Görüşler}

Gazetecilere göre yanlış bilginin önlenememesinde Dünya Sağlık Örgütü (DSÖ) ve Sağlı Bakanlığı'nın yeterli bilgi paylaşmaması ile yanlış gazetecilik pratikleri de etkili olmuştur. Hatalı gazetecilik pratikleri olarak tık/rating elde etmek amaciyla korku çekiciliğinden faydalanmak, uzman olmayan kişilerden görüş alınması, sağlık muhabiri olmayan kişilere haber yaptırılması, zaman baskısı ve rekabet nedeniyle içeriklerin doğruluğunun teyit edilmemesi sıralanmıştır. 
Gazetecilerin DSÖ ve Sağlık Bakanlığı'na ilişkin eleştirileri şöyledir:

Ayşenur Asuman Ŭgur._Vaka ve hasta sayısı arasındaki farkın Sağlık Bakanlığı tarafindan geç açıklanması en büyük yanlışlardan biriydi. Il il, bölge bölge virüsün ă̆ırlıklı olarak yaygınlı̆̆ da geç açıklandiğı için pandemi yönetiminin aslında başından beri çok da sağllkll sürdürülemediği söylenebilir. Ama devletimizde iyi niyetli ve her koşulu düşünerek her türlü kararı eminin almıştır. Alanında uzmanlaşmamış gazeteciler, televizyoncular, editörler de klsmen sorumlu. Bir güven kaybı da tutarsiz bilgiler veren ve parayı veren düdüğ̈̈ çalar misali bir yönetim anlayışını dönem dönem sergileyen Dünya Sağlık Örgütü açısından yaşadık.

Ayşegül Aydoğan Atakan: Gerek ülkemizde Să̆lık Bakanlı̆̆ı'nın gerekse küresel anlamda DSÖ’nün bilgi kirliliği ile yeterince mücadele etmediğini veya etkisiz kaldı̆̆ını söyleyebilirim. Yanlış bilgi bilindiği gibi 6-7 kat daha hızll yayıllyor. Ancak bu durum karşısında yanlış bilgiyi doğrusuyla düzeltmek, olduğu haliyle bırakmamak da oldukça önemli diye düşünüyorum.

Gazetecilere göre tıklanma kaygısı, uzmanlık gerektiren bir alan olan sağlıkta uzman olmayan muhabirlere haber yaptırılması ve konunun uzmanı olmayan kişilere haber kaynağı olarak yer verilmesi gibi hatalı gazetecilik pratikleri de yanlış bilginin önlenememesinde etkili olmuştur.

Gazetecilerin görüşleri doğrultusunda kelime benzerliğine göre kümelenmiş öğeler aşağıda yer alan küme analizinde gösterilmiştir.

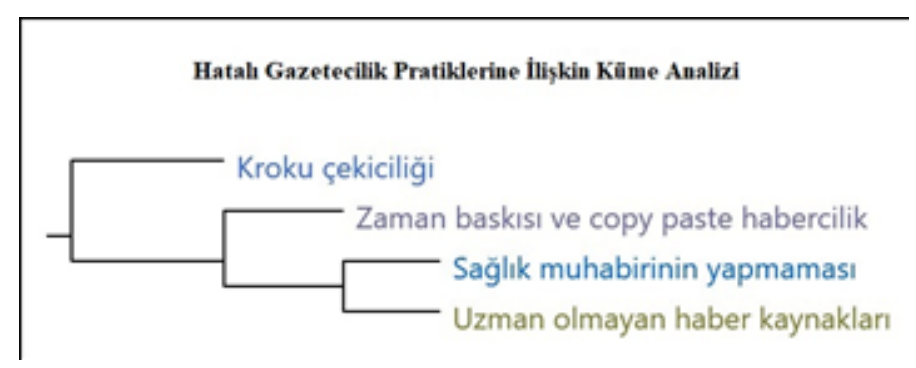
Grafik 3. Yanlış Bilginin Yayılmasında Etkili Olan Hatalı Gazetecilik Pratiklerine İlişkin Küme Analizi
Görseli.

Gazetecilerin konuya ilişkin görüşleri şöyledir:

Fatma Demir Turgut: Să̆lıkhaberciliği uzmanlıkisteyen bir alan. Şu an baktı̆̆ımızda herkes sağlık haberi yapıyor. Oysa bu alanda uzmanlaşmak yılları alabiliyor. Gazeteciler arasında da tam anlayamamaktan dolay yanlış bilgilerin yayıldı̆̆ olabiliyor. Çok yakın zamandan olan bir haber örnek vermek istiyorum. "45 gün önce aşı olan doktor koronavirüsten öldü” başlı̆̆a attığınızda aşıların hiçbir işe yaramadığı anlamı çıkıyor. Haberin içeriğinde de açılayıcı doğru dürüst bilgi yok. Oysa Doktor Bey, ilk dozu olduktan bir süre sonra hastalı̆̆a yakanmış. İkinci doz aşıyı olamamış. Neredeyse 20 gün 
hastanede kalmış. Bu tür haberler çok zarar veriyor.

Mesude Erşan: Doğru kaynakları bilmemek, kullanamamak da önemli bir sorun tabii. Tam da burada, uzmanlaşmanın önemine değinmek isterim. Uzman muhabir güvenilir kanyakları bilir, onlara ulaşır. Hangilerinin manipülatif, hangilerinin bilimsel ve gerçek olduğunu ayırt edebilir. Şüphesi varsa, aydınlatabilir. Şarlatanı ile bilim insanını ayırt edebilir. Düzgün, vicdanl, iyi bilenlerin anlattıklarını önemser ve aktarır

Melike Şahin: Virüsle ilgili bir branşta uzmanlaşmamış, bu konuda çalışmamış medyatik kişilere medyada yer verilmesi çok büyük sorundu. "kelle paça virüsten koruyor", "sarımsak virüsü öldürüyor" diye başlıklar atılırsa tıklanır da cazip de gelir. Virüsten korunmak için dezenfektan içen insanlar başvurdu acillere. Çok hassas bir süreç ve haberlerde hangi konu için kime söz verdiğiniz çok önemli.

Özay Erad: Sanırım 'önce ben verdim', 'ben yazdım', 'ben yayınladım' kayglsiyla hareket bu sorunun en doğru cevabı. Aslında zaman tanınmıyor, habercilikteki 'zamanla yarış'ne yazık ki săğlı haberciliğinde de ön plana çıkıyor.

\section{Gazetecilerin Önerileri}

Gazeteciler infodeminin önlenmesi amaciyla gazetecilere ve haber tüketicilerine ilişkin önerilerini paylaşmıştır. Gazetecilere göre okurların sağlık okuryazarlığının geliştirilmesi önemli bir süreçtir. Gazetecilikte uzmanlaşma ve haber medyasında doğru kaynaklara yer verilmesi önemli adımlardır. Gazetecilerin, meslektaşlarına yönelik önerileri şöyledir:

Ayşegül Aydoğan Atakan: Salgın boyunca uzmanların da sıkça dikkat çektiği gibi yanlış bilgi, virüsün ve salgının kendisinden çok daha öldürücü olabiliyor. Salgın, uzman muhabirliğin önemini ve gerekliliğini bir kez daha ortaya koydu. Bu doğrultuda; Yapılan haberlerde halk sağlığı öncelenmeli, kamuoyunu korkutucu, yanlış yönlendirebilecek sansasyonel içeriklerden uzak durulmalı. Haberlerde konunun uzmanı bilim insanları seçilmeli, mümkün olduğunca tıbbi literatür yerine yalın bir dille haberler hazırlanmalı, sağduyulu mesajlara yer verilmelidir. Aşıyla ilgili haberlerde doğru kaynaklardan doğrulatılmayan, asılsız bilgilere yer verilmemeli. Uzmanlık dernekleri, meslek örgütleri gibi haber kaynaklarına şüpheli içerikler söz konusu olduğunda mutlaka başvurulmalı.

Melike Şahin meslektaşının sözlerine şunları eklemiştir: "Haberin kaynăğ çok önemli. Mutlaka bilimsel bir makale baz alınmalı. Iddialar üzerinden konuşmak salgın gibi hassas bir süreç için fazla iddial. Bir de bir uzman her konuda uzman olamaz. Buna dikkat etmek gerekiyor. Ünlü olması her zaman çok iyi bir uzman olduğu anlamına gelmeyebilir. Bunun hassasiyetiyle haber yapmak gerekiyor. Ve yanlış anlaşılmanın insan hayatını etkileyebileceğini akıldan çıkarmamak gerekiyor."

Gazeteci X. Doğru kaynă̆a ulaşma, ilk kaynaktan yayılan bilginin doğruluğunu araştırma, haberi tek kaynak yerine görüş̧ çeşitliliğine dayandırarak verme önemli katkı sağlayabilir.

Özay Erad ise pandemide oluşturulan bilim kurulu gibi "sağlık haberleri kurulu" 
oluşturulması gerektiğini ifade ederek, bu kurulun sağlık haberlerinin bilgilendirilmesi ile ilgili bir rol üstlenebileceğine işaret etmiştir.

Gazeteciler, sağlık okuryazarlı̆̆ının geliştirilmesinin de infodeminin önlenmesinde etkili olacağı görüşündedir. Bu görüşlerden bazıları şöyledir:

Ayşenur Asuman Uğur: Okur şu soruları sormalı. Bilginin kaynağı nedir? Bir haberin çıkması en çok kimin işine yarar? Burada bütünün hayrı ve halk sağlığı açısından olayı değerlendirmek lazım. Ama belki hepsinden önemlisi de doğruyu yanlıştan ayırabilen, analitik düşünebilen, değerlendirme, kıyaslama kapasitesine sahip özetle sağlık okuryazarlığı yüksek vatandaşlar zaten bunlara dikkat edeceklerdir. Bu nedenle toplumun sağlık okuryazarlık düzeyini artırıcı çalışmaların da artırılması gerekir.

Fatma Demir Turgut: Maalesef bu dönemde gördük ki sağlık-okuryazarlığı konusunda toplum çok geride. Sağlık okuryazarlığı artırılmalı.

Ayşegül Aydoğan Atakan: Okurlar "koronaya karşı doğal reçete" başlığıyla sunulabilen haber ve bilgilere şüpheyle yaklaşmalıdır. "Aşıda şok gelişme" "aşıdan şüpheli ölüm” gibi sansasyonel başlıklarla verilen haberlere karşı dikkatli olunmalı. Okuyucular, takip ettikleri basın kuruluşlarında sağlık haberlerini sürekli aynı kişinin yapıp yapmadığı konusunda da farkındalık oluşturabilir. Ayrıca bilimsel kanıta dayanmayan köşe yazıları ve komplo teorisyenlerinin argümanlarına hizmet edecek bilim dışı söylemler içeren makaleler ciddiye alınmamalı. Köşe yazılarının sıklıkla kişisel yoruma dayandığ unutulmamali.

Gazetecilerin görüşleri özetlendiğinde, sağlık alanında uzmanlaşma ve haberlerde sadece uzman haber kaynaklarına yer verme konusunda önerileri dikkat çekmektedir. Gazeteciler, okurların sağlık okuryazarlığının artırılması için de çalışmalar yapılması gerektiğine işaret etmektedir.

\section{Sonuç ve Öneriler}

Yanlış algılamalar, davranışları etkilediğinde anlamlıdır ve salgın gibi olağanüstü durumlar sırasında yanlış algılamalar ölümcül olabilir. Pandemi döneminde, medya yaşanan krizle ilgili gelişmeleri ve olayları anlatarak kitlelerle bağlantı kurmuş, bu çerçeveleme, medya mesajlarının bir kamuoyu oluşturmasına neden olmuştur. İnsanların 'korkulan' koronavirüse ilişkin algısı ve yorumu, doğal olarak virüsün medyada bu çerçevelenme biçiminden kaynaklanacaktır. İnsanlarda, duruma göre daha fazla sağlık komplikasyonuna yol açabilecek gereksiz panik yaratmaktan kaçınmak için medyanın kritik bir konuyu orantısız bir şekilde gündeme taşımaması önemlidir. Salgının yapıcı bir şekilde yayınlanması, halkın salgın korkusuyla başa çıkmasına yardımcı olacaktır.

Bu anlamda çalışmamız pandeminin, medyanın haber üretimi sırasında benimsediği kuralları anlamlandırmış, ek olarak, infodeminin uzman sağlık gazetecileri arasındaki etkisi ve yansımasını ölçmüştür. Bu amaçla çalışmada öncelikle "medyanın kriz dönemlerinde haber üretimi ve riskleri” ve "infodemiye sosyal medyanın etkisi” kavramları açısından çerçeve çizilmiştir. 


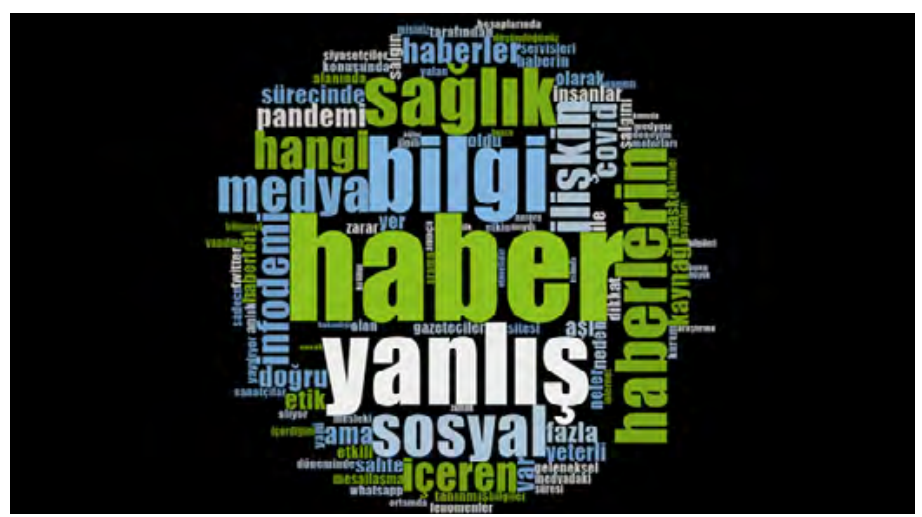

Grafik 4. Kelime Bulutu. Gazetecilerin İnfodemi Sürecinde Sağlık Haberciliğinin Rolüne İlişkin Görüşleri

Bilgi tüketim alışkanlıklarına ve medyanın haber üretim süreçlerini analiz etmek üzere yürütülen çalışma kapsamında, gazetecilerin, salgın sırasında gerçek bilgi ve yalan haber üretimi konusundaki endişelerini ortaya koymaları açısından önem taşımaktadır. Aynı zamanda sağlık gazetecilerinin, infodemi salgınındaki bilgi kirliliğine ve yalan habere yönelik tepkilerini, haber üretim ve tüketim pratiklerine yönelik eleştirilerini de ortaya koymaktır. Bu amaçla çalışmada öncelikle "medyanın kriz dönemlerinde haber üretimi ve riskleri" ve "infodemiye sosyal medyanın etkisi" kavramlarıyla çerçeve çizilmiştir.

Sağlık habercilerinin yanlış bilgi içeren haberlerin yayıldığı mecraya ilişkin görüşleri bir arada değerlendirildiğinde, sosyal ağların ve Whatsapp'ın yanlış bilgi içeren haberlerin yayılmasında ana kaynak olarak görüldüğü tespit edilmiştir. Dijital medya gibi haber medyası da bu süreçte kötü bir sınav vermiştir. Gazeteciler yazılı basını bu süreçte daha güvenilir bir kaynak olarak değerlendirmiştir.

Sağlık habercilerine yanlış bilginin kaynağı da sorulmuştur. Twitter, Facebook gibi sosyal ağlarda, Whatsapp gruplarında ve haber medyasındaki haberlerde dolaşıma giren bu bilgilerin kimler tarafından üretildiği sorusuna yanıt aranmıştır. Sağlık habercilerine göre yanlış bilgilerin önemli bir kısmında haberin kaynağı belirsizdir.

Sağlık habercilerinin sosyal ağlardaki yanlış bilgilerin yayılmasında "kim"lerin etkili olduğuna ilişkin soruya verdikleri yanıtlar ise çarpıcıdır. Gazeteciler, yanlış bilgilerin yayılmasında en fazla konunun uzmanı olmayan hekimlerin yaptıkları paylaşımlar ile bu hekimlerin verdiği yanıltıcı içerikleri yine sosyal medya hesaplarında paylaşan gazeteci, siyasetçiler, fenomenler ve içerikleri sorumsuzca paylaşan diğer sosyal medya kullanıcılarının etkili olduğuna işaret etmektedir. Yanıltıcı ve sansasyonel bilgiler paylaşan hekimlerin uzman adı altında ekrana çıkarılması da gazetecilere göre infodemi de etkili olmuştur.

Gazeteciler infodemiye yol açan içeriklerin çoğunlukla kaynağı belirsiz olduğu görüşündedir. İnfodemiye yol açan Covid 19 salgınına ilişkin yanlış bilgi içeren haberlerin üretilme nedeni, sağlık habercileri tarafından üç ana kategoride değerlendirilmiştir. Bunlar yanlış bilgiyi kontrol etmeden, bilinçsizce haberleştirme; takipçi kazanma amaciyla üretme, kaos yaratmak ve bundan beslenmek amaciyla kasıtlı olarak üretmedir. 
Gazetecilere göre infodemiye yol açan en fazla yalan haber aşı ve maske konusunda üretilmiştir. Gazetecilere göre yanlış bilginin önlenememesinde Dünya Sağlık Örgütü (DSÖ) ve Sağlık Bakanlığı'nın yeterli bilgi paylaşmaması ile yanlış gazetecilik pratikleri de etkili olmuştur.

Gazetecilere göre tıklanma kaygısı, uzmanlık gerektiren bir alan olan sağlıta uzman olmayan muhabirlere haber yaptırılması ve konunun uzmanı olmayan kişilere haber kaynağı olarak yer verilmesi gibi hatalı gazetecilik pratikleri de yanlış bilginin önlenememesinde etkili olmuştur.

Bu noktada, Şubat 2021 tarihinde bir açıklama yaparak infodemi ile mücadelenin kurallarını açıklayan ESAM'ın da önerileri ve görüşülen sağlık gazetecilerinin görüşleri dikkate alındığında, topluma verilecek mesajlarda halk sağlığını önceleyen etik anlayıştan taviz verilmemesi ve yapılan haberlerde uzmanlık alanına sahip bilim insanlarına yer verilmesi gerektiği açıktır. Asılsız bilgilerin filtrelenmesi ve doğruluğu teyit edilmeyen ya da uzmanından onay alınmayan bilgilerin paylaşılmaması bir diğer önemli husustur. Haberlerin okunması ya da tıklanması için sansasyonel tanımlamalardan uzak durulması, bilimsel kanıta dayanmayan yazıların ciddiye alınmaması, komplo teorisyenlerinin argümanlarına yardımcı olan haberlerin paylaşılmaması şarttır.

Kamunun bilme hakkı vazgeçilmez olandır, bu doğrultuda kamu politikalarını oluşturan ve icra edenlerin kamuoyunu şeffaf şekilde bilgilendirmesi, diğer taraftan gazetecilerin özdenetim mekanizmalarına işlerlik kazandırması büyük önem taşımaktadır. Medyanın vazgeçilmezi olduğu gibi sosyal medya paylaşımlarında da asıl amaç hakikatten ve bilimsel olandan vazgeçmemek olmalıdır.

\section{Kaynaklar}

Brewster, T.(2020). Coronavirus 'cure'claims getFTC warning, so maybe don't drink silver. Forbes. https://www.forbes.com/sites/thomasbrewster/2020/03/09/teas-essentialoils-and-drinking-silver-ftc-warns-about-dubious-coronavirus-cures/\#3 da $43 \mathrm{f} 2 \mathrm{e} 1 \mathrm{cba}$, Erişim tarihi: 5 Haziran 2021.

Chan, A. K., Nickson, C. P., Rudolph, J. W., Lee, A., ve Joynt, G. M. (2020). "Social media for rapid knowledge dissemination: early experience from the COVID $\square 19$ pandemic". Anaesthesia. S. 1579-1582.

Cumhuriyet. (2021). "Sağlık habercilerinden aşı haberi uyarısı". Cumhuriyet Gazetesi. https://www.cumhuriyet.com.tr/haber/saglik-habercilerinden-asi-haberiuyarisi-1809255, Erişim tarihi: 27 Ocak 2021.

Çapl1, B., ve Taş, O. (2010). "Kriz haberciliği”. Televizyon Haberciliğinde Etik, s. 237-251.

Dechêne, A., Stahl, C., Hansen, J., \& Wänke, M. (2010). "The truth about the truth: A meta-analytic review of the truth effect". Personality and Social Psychology Review, 14(2), s. 238-257. 
Dursun, A. (2020). "Iran: Death toll from toxic alcohol rises to 180". Anadolu Ajans1. https://www.aa.com.tr/en/health/iran-death-toll-from-toxic-alcohol-risesto-180/1771659, Erişim tarihi: 2 Haziran 2021.

Eysenbach, G. (2002) . "Infodemiology: The epidemiology of(mis) information”. The American journal of medicine, 113(9), s. 763-765.

Fox, S. (2006). Online Health Search 2006. http://www.pewinternet.org/2006/10/29/ online-health-search-2006/, Erişim tarihi: 30 Mart 2021.

Fung, I. C.-H., Fu, K.-W., Chan, C.-H., Chan, B. S. B., Cheung, C.-N., Abraham, T., ve Tse, Z. T. H. (2016). "Social Media's Initial Reaction to Information and Misinformation on Ebola”, August 2014: Facts and Rumors. Public Health Reports, 131(3), s. 461-473.

Furedi, F. (2001). Korku kültürü: Risk almamanın riskleri. İstanbul: Ayrıntı yayınları.

Garrett, R. K., Weeks, B. E., ve Neo, R. L. (2016). "Driving a Wedge Between Evidence and Beliefs: How Online Ideological News Exposure Promotes Political Misperceptions". Journal of Computer- Mediated Communication, 21(5), s. 331-348.

Geçer, E. (2020). TRT Akademi İnfodemi Araştırması Raporu, https://trtakademi. net/wp-content/uploads/2020/08/TRT-Akademi-Infodemi-Arastirmasi-Raporu.pdf, Erişim tarihi: 30 Mayıs 2021.

Giddens, A., ve Pierson, C. (2001). Modernliği Anlamlandırmak. İstanbul: Alfa Kitabevi.

Gough, A., Hunter, R. F., Ajao, O., Jurek, A., McKeown, G., Hong, J., ve Kee, F. (2017). "Tweet for behavior change: using social media for the dissemination of public health messages". JMIR public health and surveillance, 3(1), e14.

Honigsbaum, M. (2013). "Regulating the 1918-19 pandemic: Flu, stoicism and the Northcliffe press", Medical history, 57(2), s. 165-185.

Kemp, S. (2020). "Digital 2020: October Global Statshot". DataReportal, https:// datareportal.com/reports/digital-2020-october-global-statshot. Erişim tarihi: 10 Mart 2021.

Kim, L., Fast, S. M., ve Markuzon, N. (2019). "Incorporating media data into a model of infectious disease transmission". PloS one, 14(2).

Kırık, A. L. ve Orkan, S. (2021). "Olağandışı Durumlarda İletişim, İnfodemi ve Toplum Psikolojisi: Koronavirüs Pandemisi Örneği”, Sosyal Psikoloji El Kitabı, Ekmel Geçer ve Meltem Serdar (Ed.), s. 309-327, Ankara: Grafiker Yayınları.

Kouzy, R., Abi Jaoude, J., Kraitem, A., El Alam, M. B., Karam, B., Adib, E., ve Baddour, K. (2020). "Coronavirus goes viral: quantifying the COVID-19 misinformation epidemic on Twitter". Cureus, 12(3).

Kushner, J. (2020). "The role of social media during a pandemic". Khoros, Industry Trends. https://khoros. com/blog/social-medias-role-during-covid-19. Erişim tarihi: 15 Mayis 2021. 
Llewellyn, S. (2020). "Covid-19: how to be careful with trust and expertise on social media". BMJ, 368 .

Marantz, A. (2020). “Alex Jones's Bogus Coronavirus Cures”. The New Yorker. https://www.newyorker.com/magazine/2020/04/06/alex-jones-bogus-coronavirus-cures, Erişim tarihi: 4 Haziran 2021.

Mitchell, A., Gottfried, J., Barthel, M., ve Shearer, E. (2016). "The Modern News Consumer". Pew Research Center's Journalism Project. https://www.journalism. org/2016/07/07/the-modern- news-consumer/, Erişim tarihi: 15 Haziran 2021.

Mourad, A., Srour, A., Harmanai, H., Jenainati, C., ve Arafeh, M. (2020). “Critical impact of social networks infodemic on defeating coronavirus COVID-19 pandemic: Twitter-based study and research directions". IEEE Transactions on Network and Service Management, 17(4), s. 2145-2155.

Newman, N., Fletcher, R., Kalogeropoulos, A., Levy, D. A. L. ve Nielsen, R. K. (2017). "Digital News Report 2017". Reuters Institute. https://reutersinstitute.politics. ox.ac. uk/sites/default/files/Digital\%20News\%20Report\%202017\%20web_0.pdf, Erişim tarihi: 20 Haziran 2021.

O'Donnell, B. (2020). "Here's why 5G and coronavirus are not connected". USA Today. https://www.usatoday.com/story/tech/columnist/2020/03/21/did-5-g-causecoronavirus-covid-19-pande mic/2873731001/, Erişim tarihi: 21 Mayıs 2021.

Pakkan, Ş. (2020). "Heisenberg mi, Boosterism mi: "Medyada Yararı" Çıkmazı" içide Sosyal ve Beşeri Bilimlerde Teori ve Araştırmalar II. Ankara: Gece Kitaplığı. s. 345-362.

Pakkan, Ş., İldaş, G. (2021). "Medyanın Pandemi Sınavı: Covid-19 Salgınının Türkiye'de Haber Tüketim Alışkanlıklarına Etkisi”. 1, 229-247. Turkish Studies-Social Sciences.

Palmer, A. (2020). “Amazon removes hundreds of thousands of 'high-priced offers' amid coronavirus price gouging”. CNBC. https://www.cnbc.com/2020/03/06/amazonremoves-530000-products-amid-coronavirus-price-gouging.html., Erişim tarihi: 29 Mayıs 2021.

Radzikowski, J., Stefanidis, A., Jacobsen, K. H., Croitoru, A., Crooks, A., ve Delamater, P. L. (2016). "The Measles Vaccination Narrative in Twitter: A Quantitative Analysis". JMIR Public Health and Surveillance, 2(1).

Schram, G. N. (1993). Toward a response to the American crisis. Christendom: Christendom Press.

Sharma, M., Yadav, K., Yadav, N., ve Ferdinand, K. C. (2017). "Zika virus pandemic Analysis of Facebook as a social media health information platform". American Journal of Infection Control. 45(3), s. 301-302.

Stone R. (2020). "Iran confronts coronavirus amid a 'battle between science 
and conspiracy theories"'. Science. https://www.sciencemag.org/news/ 2020/03/iranconfronts-coronavirus-amid-bat tle-between-science-and-conspiracy-theories. Erişim tarihi: 30 Nisan 2021.

WHO, (2020a). Developing trans-disciplinary science: infodemiology, the science behind infodemic management. Erişim Adresi: https://www.who.int/docs/default-source/ coro naviruse/situation-reports/20200707-covid-1 9-sitrep-169.pdf?sfvrsn=c6c69c88_2.

WHO. (2020b). Coronavirus disease 2019 (COVID-19): situation report, 42. Erişim Adresi: source/coronaviruse/situation-reports/20200 305-sitrep-45-covid-19. pdf?sfvrsn=ed2ba78 b_4.

WHO. (2020c). Novel Coronavirus (2019-nCoV) situation report - 13: World Health Organization. Erişim Adresi: https:/www.who.int/ docs/default-source/coronaviruse/ situation-r eports/20200202-sitrep-13-ncov-v3.pdf?sfvr sn=195f4010_6.

WHO. (2020d). Infodemic Management - Infodemiology World Health Organization; 2020 Erişim Adresi: Https://Www.Who.İnt/Teams/Risk- Communication/ İnfodemic-Management.

Destekleyen Kurum/Kuruluşlar: Herhangi bir kurum/kuruluştan destek alınmamıştır.

Çıkar Çatışması: Herhangi bir çıkar çatışması bulunmamaktadır 